\title{
Public incentives and environmental taxation for a sustainable C\&D waste management in Spain: an industrial ecology challenge
}

\author{
Nuria Calvo ${ }^{1}$ \\ Laura Varela-Candamio ${ }^{{ }^{*}}$ \\ Isabel Novo-Corti ${ }^{1}$ \\ 1 Jean Monnet Research Group of Competition and Development, Faculty of \\ Economics and Business, Campus de Elviña, s/n, A Coruña 15071, Spain \\ *Corresponding author: laura.varela.candamio@udc.es. Phone number: +34 981167 \\ 000 Fax number: +34 981167070
}

Nuria Calvo is an associate professor at the University of A Coruña, $\mathrm{PhD}$ in Business Administration and degree in Economics and Industrial Psychology. After twelve years working as consultant in several firms (Accenture, Inditex), currently she works as a researcher in the Economic Analysis and Business Administration Department at University of A Coruña (Spain). Her research focuses on modelling the incentives policies in organizations, and the assessment of different strategic approaches in technology transfer and spin-offs. She has published in System Dynamics Review, Service Business, Transformation in Business and Economics, Sustainability, International Journal of Organizational Analysis, European Research Studies Journal and she has been visitor professor in University of Porto (Portugal) and The Dublin Institute for Technology (Ireland).

Laura Varela-Candamio is an assistant professor at the University of A Coruña and Tutor at the Associate Centre of A Coruña at the Spanish National Open University (UNED), PhD in Economics and degree in Economics. She works as a researcher in the Economic Analysis and Business Administration Department at University of A Coruña (Spain). Her research focuses on fiscal policy, public finance, human behavior and regional economic growth. She also works on innovative education, ICT and social exclusion groups, especially in higher education. She has published in Economics Letters, Applied Economics, Sustainability, El Trimestre Económico or Computers in Human Behavior. She also has presented his research in several international conferences and she has been visiting scholar in University of Porto (Portugal), Suffolk University (USA) and University of Illinois (USA).

Isabel Novo-Corti is associate professor at the University of A Coruña and Tutor at the Associate Centre of A Coruña at the Spanish National Open University (UNED), PhD in Economics and degree in Economics. She is the head of the Department of Economic Analysis and Business Administration of the University of A Coruña. She works as a researcher in the Economic Analysis and Business Administration Department at 
University of A Coruña (Spain) and in the University Institute of Maritime Studies at Univertsity of A Coruña. Her research focuses on inclusive and gender policies and groups at social exclusion risk, human behavior and maritime affairs. She has published in Política y Gestión, Anales de Psicología, or Computers in Human Behavior. She also has presented his research in several international conferences and she has been visiting scholar in Washington University (Missouri, USA), Reading (United Kingdom) and Harvard University (Massachusetts, USA). She is a member of the scientific committee of several national and international conferences, for example National Economy (Association of Economists Galicia, A Coruña, 2005) and ICABE, in 2009 (Kavala , Greece), 2010 (A Coruña) and 2011 (Athens , Greece).

\begin{abstract}
By 2020, according to the recent Spanish legislation (Law 22/2001), the amount of nonhazardous construction and demolition waste (C\&D waste) must be at least $70 \%$ by weight of the produced. However, the current behavior of the stakeholders involved in the waste management process make this goal difficult of achieving. This article examines a number of fiscal instruments to promote the prevention and control of pollution by encouraging the use this type of waste. The heterogeneity of these measures at local level requires the development of a statewide law that governs the actions designed to promote joint coordination and serve to achieve the goal of state protection. The target areas for the tax route will focus mainly on producer responsibility and the promotion of green technologies. From a causal analysis of the problem, we have designed a management model to analyze the impact of incentive policies for the Administration to use $C \& D$ waste. This model encourages a broader understanding of the technical and socioeconomic implications of sustainable construction.
\end{abstract}

Keywords: C\&D waste, sustainable construction; policy instruments; environmental taxation; management model.

JEL Classification: H2, H3, L1 


\section{INTRODUCTION}

Within the environmental objectives of the EU, construction and demolition waste (hereinafter C\&D waste) represent one of the largest waste streams. After air and water, $C \& D$ waste is the first natural product of consumption in the EU with close to 2,000 million tons per year level, which represents 6 tons / EU citizen. Therefore, landfilling of this waste is a major problem, especially in the most densely populated European countries (European Commision, 2011). Fortunately, the selection of much of the material allows some of them to reach a market value, once managed and recycled. Moreover, the environmental impact of the production of recycled C\&D waste is greatly reduced with respect to the management of natural aggregates from quarry, even with similar purposes (Aneiros Rodríguez, 2008).

Our work present a model based on a non-technical closed loop system by introducing a new focus to explore the options for sustainable constructions goals through an environmental management system (EMS). An EMS is a system and database which integrates procedures and processes for training of personnel, monitoring, summarizing, and reporting of specialized environmental performance information to internal and external stakeholders of a firm (Sroufe, 2003). This approach reinforces the importance of new management systems that encourage the use of aggregate coming from $C \& D$ waste as building materials by construction companies, instead of natural aggregates (Brito de Aquino, 2013). However, from the construction companies' point of view, the choice between aggregates from quarries or from C\&D waste will depend on the costbenefit analysis, more than social issues (Dijkgraaf and Vollebergh, 2004). In this sense, the legal and task regulation will determine the amount of waste reutilized by companies, reducing the stock of C\&D waste (Leal Filho et al., 2013).

However, the profile of the C\&D waste sector in Spain has not developed standards to ensure products of sufficient quality for a number of uses. This circumstance makes implementation of Industrial Recycling Systems through a profitable management difficult. As a result, potential consumers are not motivated to use recycled material due to image problems, in some cases and, the preference for other higher quality products, in others (Galindez, 2003). This is the main reason why the development of recycling in Spain is at a very low level compared to other Member States. Since market forces are those that are "burdening" the process of development of recycling in Spain, the use of 
economic instruments and environmental laws are manifested as key to correct these malfunctions in the marketplace (Calvo et al., 2014). Indeed, market-based instruments (taxes, subsidies and other incentives) are better than laws promoting environmental innovation (Kemp and Pontoglio, 2011).

The aim of this paper is to advance the study of different guidelines for the adoption of an effective EMS for construction sector in Spain, with patterns that can be expected in other European countries, especially those with low recycling and reuse. The EMS proposed in this paper reveals the successful tools in industrial ecology for sustainable development in countries with a marginal activity on C\&D waste management and also establish channels of communication between business stakeholders and the government to the challenges of inter-organisational environmental management. Particularly, our paper summarizes the characteristics of governmental intervention on the Spanish management of C\&D waste at a regional level, divided into three instruments: regulation, tax instruments and other market-based instruments. This comparison highlights a heterogeneous taxation with big disparities in the degree of development among regions.

The structure of this paper is as follows. Section 2 analyzes the current situation in the production and management of C\&D waste in Spain compared to the other EU member countries. Section 3 presents an EMS model and the importance of public initiative in the management of C\&D waste for the Spanish case. Section 4 shows the public policy initiatives developed in C\&D waste issues, particularly focus on environmental taxation in Spain, by both the central and regional governments. Finally, section 5 concludes.

\section{C\&D waste management in Spain: a marginal development}

According to the European Waste List, the C\&D waste are defined as waste coming from construction, renovation and demolition of buildings, public works and infrastructure works. Most of the C\&D wastes are inert (usually between 70\% and 90\%) although the increasing use of non-inert materials may modify this ratio in the future. The composition of the C\&D Waste is usually quite heterogeneous since it depends on several factors such as own local conditions of each region, the different legislative frameworks and the diversity of actors involved in this industry. However, their distribution is relatively uniform. Thus, in the whole EU, demolition waste comprise 
between $30-50 \%$, waste restoration / rehabilitation between $30-50 \%$ and construction waste accounts for between 10-20\%.

In the case of Spain, building represents $70 \%$ of C\&D waste generated while civil work represents only $27 \%$ in 2005 . As it is shown in Table 1 , although the C\&D waste generation has increased considerably in the pre-crisis years, the distribution by type of work has remained almost constant. These results highlight the need to regulate the activity of the producer as much of the production of $C \& D$ waste generated in the private construction work.

Table 1 Generation of C\&D waste by type of work

\begin{tabular}{|c|c|c|c|c|c|}
\hline Type of work & $\mathbf{2 0 0 1}$ & $\mathbf{2 0 0 2}$ & $\mathbf{2 0 0 3}$ & $\mathbf{2 0 0 4}$ & $\mathbf{2 0 0 5}$ \\
\hline Building & $17,667.189$ & $17,495.175$ & $20,298.601$ & $23,054.631$ & $25,427.665$ \\
\hline Civil Works & $6,543.403$ & $6,479.649$ & $7,518 ., 000$ & $8,538.752$ & $9,417.654$ \\
\hline $\begin{array}{c}\text { Total C\&D waste } \\
\text { generated }\end{array}$ & $24,210.592$ & $23,974.824$ & $27,816.601$ & $31,593.383$ & $34,845.319$ \\
\hline
\end{tabular}

Source: Ministry of Public Works. Centre for the Study and Experimentation of Public Works (2009)

C\&D waste management known as 3R (reduce, reuse and recycle) varies greatly among different EU countries (Table 2). The northern European countries with a long tradition in regulated C\&D waste management (Netherlands, Denmark and Belgium) have achieved high levels of recycling, in some cases above $80 \%$. However, the southern countries (Portugal, Italy, Greece and Spain) have sufficient quality and abundant natural resources to ensure the demand for natural aggregates at moderate cost. In this context, there is a clear absence of incentives for recycling of the RCD and the market for recycled aggregates finds a very low demand. Thus, the existing recycling infrastructure is very slim. Moreover, in these countries, illegal discharges become widespread because, given the inert nature of these materials, their control is very difficult.

Table 2 Construction and demolition waste management in Europe

\begin{tabular}{|c|c|c|c|c|c|c|}
\hline \multirow{2}{*}{ Country } & Production of & Mean & \multicolumn{2}{c|}{$\begin{array}{c}\text { No. of } \\
\text { C\&D waste }\end{array}$} & \multicolumn{2}{|c|}{ Destination in percentage } \\
\cline { 5 - 6 } & (kg/inhab) & recycling & Disposal site & Recycled & Other \\
\hline
\end{tabular}




\begin{tabular}{|l|c|c|c|c|c|c|}
\hline & (mil. Tonnes) & & plants & & & \\
\hline Holland (1999) & 11.7 & 718 & 120 & 9 & 90 & 1 \\
\hline Belgium (1999) & 6.7 & 666 & 92 & 17 & 81 & 2 \\
\hline Denmark (1999) & 2.6 & 509 & 30 & 16 & 75 & 9 \\
\hline UK (1999) & 30.0 & 509 & $50-100$ & 55 & 45 & 0 \\
\hline Austria (1999) & 4.7 & 580 & 150 & 59 & 41 & 0 \\
\hline Germany (1999) & 59.0 & 720 & 1.000 & 82 & 18 & 0 \\
\hline France (1999) & 23.6 & 404 & 50 & 85 & 15 & 0 \\
\hline Spain (2005) & $\mathbf{1 0 . 3}$ & $\mathbf{2 2 9}$ & $\mathbf{5 8}$ & $\mathbf{8 3}$ & $\mathbf{1 7}$ & - \\
\hline
\end{tabular}

Source: C\&D waste Catalogue. Centre for the Study and Experimentation of Public Works. Ministry of the Environment and Rural and Marine Affairs (2009)

Focusing on the case of Spain, we observed that levels of reuse and recycling are the lowest in the EU. In addition, about $60 \%$ of the C\&D waste is removed uncontrollably in landfills, $20 \%$ is disposed of in landfills of inert or non-special waste and only $10 \%$ undergo revaluation or recycling processes. Notwithstanding the foregoing, this recycling process was significantly increasing over the years before the crisis (Table 3).

Table 3 Construction and demolition waste management (2002-2005)

\begin{tabular}{|c|c|c|c|c|}
\hline & $\mathbf{2 0 0 2}$ & $\mathbf{2 0 0 3}$ & $\mathbf{2 0 0 4}$ & $\mathbf{2 0 0 5}$ \\
\hline Recycled & 375,106 & 333,640 & 519,370 & $1,769,836$ \\
\hline Disposal site & $6,502.428$ & $7,519.755$ & $4,978.410$ & $8,544.578$ \\
\hline
\end{tabular}

Source: C\&D waste Catalogue. Centre for the Study and Experimentation of Public Works. Ministry of the Environment and Rural and Marine Affairs (2009)

This duality reveals a strong positive correlation between the highest level of development in the management of $C \& D$ waste and higher levels of existing environmental protection among these countries (Manowong, 2012). In particular, European countries that have reached the highest levels of recycling are precisely those that use legislative and fiscal instruments (Cooper, 1996). For this reason, in the last section the various tools at their disposal to improve government management and enhance the market C\&D Waste recycling them, with special attention to the Spanish case are analyzed. 


\section{The EMS model and the Spanish case of study}

The Environmental Management System (EMS) is a model that includes the concept of Extended Producer Responsibility, in order to generate widespread awareness towards sustainable construction and improve the effectiveness of waste management (Lu and Yuan, 2011), from a systemic approach. This system integrates environmental performance information to internal and external stakeholders of an organization (Sroufe, 2003). To gain an in-depth understanding of the concept of sustainable construction and to be able to put it into practice, it is necessary to be aware of the interrelations between the different principles inherent to the concept, the different stages of the construction process and the resources used (Figure 1).

Figure 1 Conceptual framework for sustainable construction

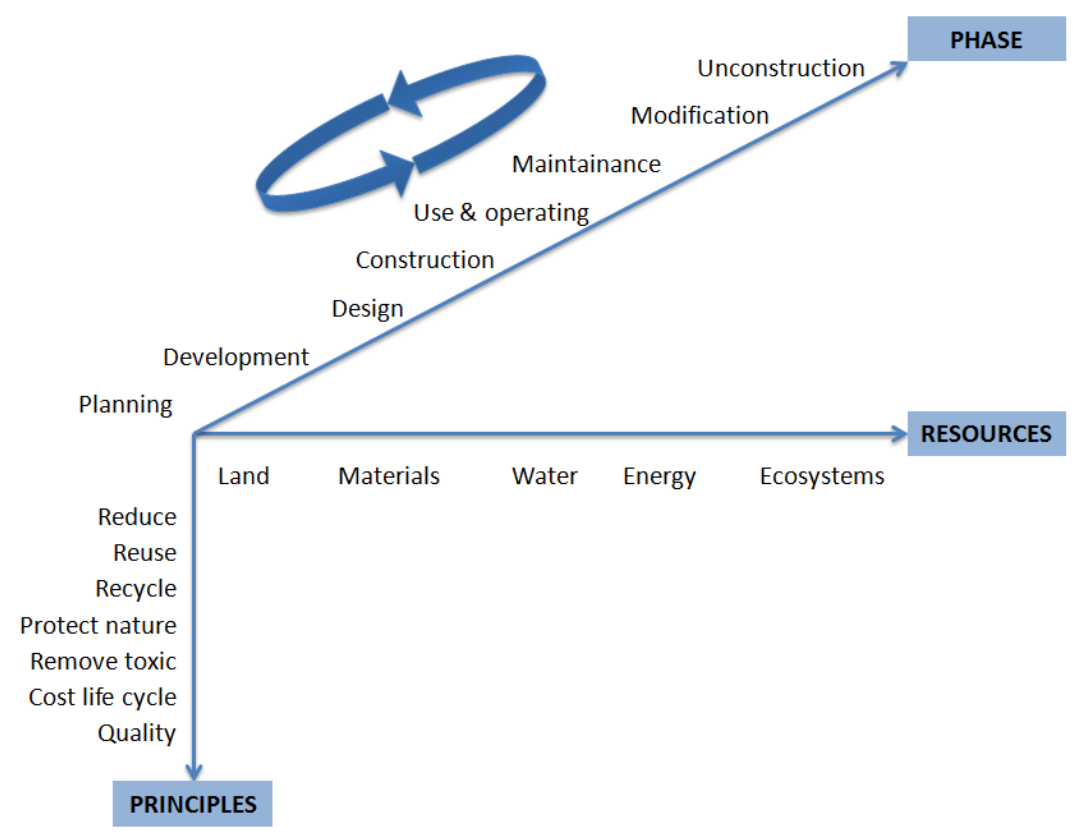

Source: Kibert (2008)

With regard to this global model, the use of waste in the composition of construction materials is a basic principle of the concept of sustainable construction, since it helps to mitigate the problem of waste management and treatment. Moreover, recycling in construction reaps a number of different benefits such as, for example, reducing the need for energy and natural resources and optimising the use of disposal sites. Along 
these lines, a kind of waste material that can be used in civil works is C\&D waste. These wastes come mainly from the demolition of buildings or from construction material debris from new buildings and small renovation works on homes and developments. This type of waste is known as "rubble", which is generated in large quantities and its volume exceeds that of domestic origin. C\&D waste is usually taken to a dump, given the favourable price conditions, with disposal costs that no other more environmentally friendly operation can compete with. Since most C\&D materials are considered to be inert or assimilable to inert, their pollution potential is relatively low. Otherwise, their visual impact is often high owing to the large volume of space they occupy and the lack of enforcement of environmental control on the lands chosen for their disposal (Dosal et al., 2012). Another negative environmental impact is due to the squandering of the raw materials involved in this type of management, for which recycling is not considered (PNRCD 2001-2006).

In order to keep in mind the pattern of behaviour currently developed in Spain, we consulted to a group of experts from public institutions and construction companies, and designed the following preliminary analysis. The demand for constructions materials is determined by the planned civil works, which is managed according to the public budget available to the Government for these purposes. Figure 2 relates the assignment of civil works, which is based on the economic budget of Government (economic issues), with the demand and use of quarried aggregates (production issues) and the environmental cost of this activity (social issue). If the environmental cost is too high to be assumed by society, public institutions are the responsible to solve the problem, assuming costs that reduce the budget for future civil works assignments. 
Figure 2. Traditional dynamic of construction sector

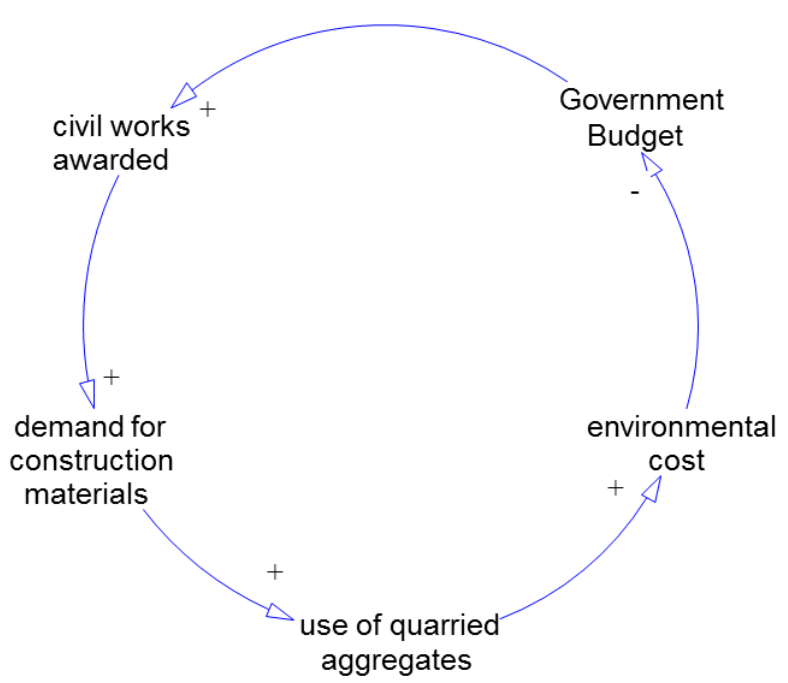

The experts also reinforce the idea that new assignments for civil works usually involve the demolition of previous constructions, and this task increases the stock of C\&D waste, generating higher environmental costs coming from the management of the pieces of rubble (Figure 3).

Figure 3. Reinforced dynamic of environmental impact

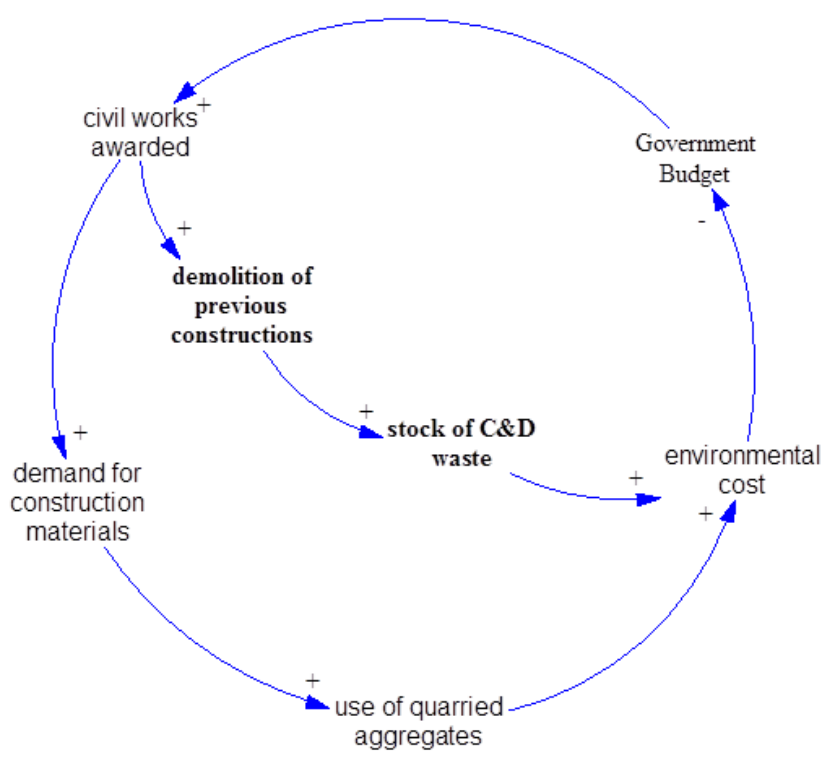


Thus, the stock of C\&D waste depends largely on the demolition of previous constructions. So, the current situation of stagnation of the construction industry in Spain could reverse the environmental impact of the rubble. However, it is important to keep in mind that this situation does not solve the problem, but it postpones the problem for later, which could perpetuate the problem in the long term (Figure 4).

Figure 4. Reversed dynamic of environmental impact

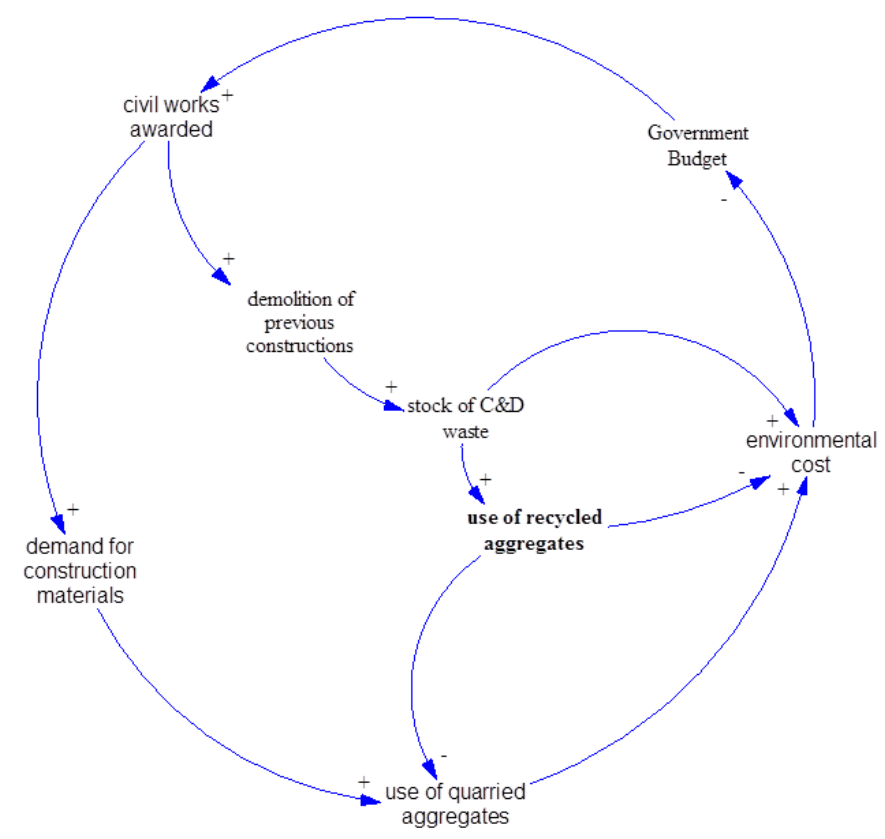

This approach reinforces the importance of new management tools that encourage the use of aggregate coming from C\&D waste as building materials by construction companies, instead of natural aggregates (Brito de Aquino et al., 2013). However, from an economic point of view, recycling is attractive when the recycled product is competitive with the raw materials in relation to both cost and quality. Recycled materials will be competitive where there is a lack of raw materials and appropriate points of discharge. Moreover, using recycled materials can make huge savings in transporting construction waste and raw materials. Therefore, from the construction companies point of view, the choice between aggregates from quarries or from $C \& D$ waste will depend on the cost-benefit analysis, more than social issues. 
In this sense, the legal and task regulation will determine the amount of waste reutilized by companies, reducing the stock of C\&D waste (Cooper, 1996). Previous studies have identified the key factors involved in this problem: Waste management regulations, Waste Management system, awareness of C\&D Waste Management, low-waste building technologies, fewer design charges, R\&D in Waste Management and vocational training in Waste Management ( $\mathrm{Lu}$ and Yuan, 2010; Lu et al., 2011). The highest recovery rates are settled in the regions with a strong demand and high use of recycled products (C\&D WASTESR, 2013), but it is important the existence of a wealthy market for recycled C\&D aggregates.

\section{Public policy and taxation in $C \& D$ waste management: the Spanish case}

The growing awareness of society for environmental protection and sustainable development has led to the need for greater involvement of the public service in this area and in particular in the construction sector. In fact, health and safety was found to have the most significant and dominant impact on the achievement of sustainable construction waste management (Manowong, 2012). As it has seen in the previous sections, regulation and market-based instruments are key points for improvement in the management and recycling of C\&D waste (Cooper, 1996). Specifically, the measures used in the EU for influence on the management of RCDs can be grouped into three types (Symonds Report, 1999; Report from the European Environment Agency, 2002; European Commission, 2004): regulation, fiscal instruments and other general (economic) measures.

\subsection{Regulation}

There is a lack of an extensive regulation in C\&D waste management in Spain. However, Spanish central government has developed some legislation in recent years. In 1998, Law of waste (Law 10/1998) and then Law of building management (Law 38/1998) as well as the Royal Decree 1481/2001 as a supplement, which transposes the European landfill directive, which regulates the elimination of waste disposal by landfill.

More specifically (but not mandatory), the National Plan for Construction and Demolition Waste (PNRCD) for 2001-2006 was approved. This National Plan sets out 
the principles of the waste management and funding mechanisms for achieving goals. On the other hand, MAM/304/2002 regulates recovery operations and waste disposal as well as the European Waste List.

The objectives of the PNRCD 2001-2006 were too ambitious and, over time, became unattainable. Therefore, a second National Plan for C\&D (PNRCD 2007-2015) waste has been developed for the period 2007-2015 where it is stated that the amount of nonhazardous C\&D waste must be at least 70\% by weight of the produced by 2020 .

Regarding legislative measures for the recovery and recycling of $C \& D$ waste, we include selective demolition or source separation, voluntary agreements and planning or control. Thus, for the laying of recycled aggregates, ECS (European Committee for Standardization) approved the norm EN 13242. "AGGREGATES NOT LINKED AND LINKED FOR USE IN CIVIL ENGINEERING AND ROAD CONSTRUCTION" that equates recycled aggregates to natural and artificial ones.

In this sense, a key measure was the requirement to allocate the waste to a recycling plant or authorized manager in the building demolition projects. Law 10/1998 defines the waste manager as the person or entity, public or private, who makes any of the operations related to the waste management. Figure manager and producer may or may not coincide in the same person. In the construction business, the holder of the waste can be each subcontractor or prime contractor; impacting, where appropriate, the costs company. Based on this law, the holders of waste shall be required to manage by themselves, deliver them to a waste manager (for recovery or disposal) or register to participate in a voluntary agreement or collaboration agreement comprising these operations. In addition, the holder of waste shall be required to pay their Corresponding costs.

Furthermore, according to the National Plan, Spanish governments should promote and encourage the creation of recycling infrastructure by the private sector. In addition, the cost of a proper management of $C \& D$ waste must be borne by producers, in application of the criteria "polluter pays". In other words, we refer to the legislation on producer responsibility.

The more expensive it is to get rid of waste material such as pure waste, the greater the producer's interest in finding an alternative route passing through some kind of 
achievement. In this sense, disposal costs of the C\&D waste, and in particular, the charges of dumping are greater when transport costs of recovery are big due to the distances between places of production, processing and storage of $C \& D$ waste. The final use of the resulting product may exceed the value for the potential user limiting the economic viability of the recycled product. For this reason, the most advanced countries have followed policies with economic penalty regarding disposal of C\&D waste without exploitation, which has decreased the total amount of $C \& D$ waste produced. This measure includes direct ban on landfill of recyclable C\&D waste, as in Germany and Holland or may refer to a selective demolition through the separation of different waste as well as the recycling of C\&D waste, as in Austria. In any case, management models aimed at avoiding landfilling of C\&D waste (restrictions or bans on the dumping) should be enhanced.

\subsection{Fiscal instruments}

Environmental taxation is another aspect of great importance in the field of C\&D waste management. Since 1997, various Member States in the EU established a system of taxation on landfill as a result of the widespread trend consisting of the so-called green tax reform (Varela Candamio and García Álvarez, 2010). This reform introduced environmental taxes thereby allowing a reduction in other taxes that generate a loss of efficiency, such as income taxes or social security contributions, keeping constant the collection. The basic model, in the words of Burgos (2005) is "revenue-neutral scheme in which environmental taxes (...) compensate for revenue losses resulting from the reduction of taxes on labor, mainly social security contributions." The change in the balance of tax principles is reflected by translating from direct to indirect taxation.

The green tax reform is also related to the concept of double dividend derived from a double benefit. On the one hand, the reduction of negative externalities and the consequent improvement of sustainable development (first dividend). On the other hand, income tax collection replace the collection of other direct taxes more distortionary (strong dividend) ${ }^{1}$ (Bovenberg and De Mooij 1994; Goulder, 1994).

\footnotetext{
1 There are some authors who criticize the latter benefit since they argue that rising commodity prices (taxing products) can generate perverse effects on inflation and international competitiveness. This theory is known as weak double dividend. In any case, an adequate tax planning could avoid the adverse effects mentioned above.
} 
For this reason, since the early nineties, environmental policies become an increasing importance in EU countries. As we know, taxes are set as the most appropriate alternative instrument. In the C\&D waste management, the tax on the disposal of C\&D waste should be the first source of income as they support most of the cost of production, being an added cost on the price of admission in landfills. Thus, this canon on the waste disposal converts waste into raw material to avoid ending up in a landfill. This measure has already been adopted in most of the member states of the EU, although with different modalities: finalist or not and specific or general.

Thus, some countries have developed other related tax figures such as the canon of classification of materials (material separation), canon of crushing infrastructure, increased price on landfill, tax on the deposit of bulky industrial waste, tax on the disposal of inert, urban or hazardous waste etc. Finally, other fiscal instrument could be the payment for the sale of this commodity with a bargain price to encourage their acquisition instead of natural or artificial aggregates.

The level of development for sustainable management of C\&D waste is very different in a country from a regional approach, both from an economic and business point of view and from the aspect of environmental impact. In the case of Spain, although progress has been marginal in most areas, there are three regions that have achieved significant growth, primarily through the fiscal impulse. These are the Spanish regions of Madrid, Murcia and Catalonia. Table 4 summarizes the characteristics of the tax on the management of C\&D waste implanted in these Spanish regions. This comparison highlights a heterogeneous taxation with an own fiscal competence among regions.

Table 4. Comparing taxes on C\&D waste in three Spanish regions. Year 2009 
Source: Adaptation from Puig Ventosa and González Martínez (2012)

\begin{tabular}{|c|c|c|c|}
\hline $\begin{array}{l}\text { Regional } \\
\text { government }\end{array}$ & Madrid & Murcia & Cataluña \\
\hline $\begin{array}{l}\text { Spanish } \\
\text { region }\end{array}$ & Madrid & Murcia & Catalonia \\
\hline Tax & Tax on disposal of waste & $\begin{array}{l}\text { Tax on storage and disposal of } \\
\text { waste }\end{array}$ & $\begin{array}{c}\text { Canon on the controlled } \\
\text { disposal of construction } \\
\text { waste }\end{array}$ \\
\hline Law & $\begin{array}{l}\text { Law 6/2003 of tax on } \\
\text { disposal of waste }\end{array}$ & $\begin{array}{c}\text { Law 9/2005 of Fiscal measures } \\
\text { in assigned taxes and own taxes } \\
\text { issues }\end{array}$ & $\begin{array}{l}\text { Law } 8 / 2008 \text { on financing of } \\
\text { infrastructure waste } \\
\text { management and fees on } \\
\text { the disposal of waste } \\
\text { residues }\end{array}$ \\
\hline Year & 2003 & 2005 & 2009 \\
\hline $\begin{array}{l}\text { Type of } \\
\text { waste }\end{array}$ & $\begin{array}{l}\text { Waste from construction } \\
\text { and demolition }\end{array}$ & Inert waste & Waste from construction \\
\hline $\begin{array}{c}\text { taxable } \\
\text { event }\end{array}$ & $\begin{array}{l}\text { Deposit of waste on land: } \\
\text {-Delivery of waste in } \\
\text { public or private landfills } \\
\text {-Abandonment in those } \\
\text { areas not covered by } \\
\text { existing legislation }\end{array}$ & $\begin{array}{l}\text {-Delivery of waste in public or } \\
\text { private landfills } \\
\text {-Abandonment of waste or } \\
\text { waste disposal in unauthorized } \\
\text { installations } \\
\text { Waste storage for more than } 2 \\
\text { years if it is inert waste without } \\
\text { express authorization by the } \\
\text { environmental body, on licensed } \\
\text { premises. }\end{array}$ & -Controlled deposition \\
\hline Tax rate & $3 € / \mathrm{m} 3$ & $3 € / \mathrm{t}$ & $3 € / \mathrm{t}$ \\
\hline Taxpayers & $\begin{array}{l}\text { Natural/legal persons or } \\
\text { entities without legal } \\
\text { personality that deliver } \\
\text { waste in a landfill or } \\
\text { abandon them in } \\
\text { unauthorized places }\end{array}$ & $\begin{array}{l}\text { Holders operating landfills } \\
\text { responsible for the abandonment } \\
\text { or dumping }\end{array}$ & $\begin{array}{l}\text { Producers of construction } \\
\text { waste }\end{array}$ \\
\hline $\begin{array}{c}\text { Substitute } \\
\text { taxpayer }\end{array}$ & Holders operating landfills & No substitutes & $\begin{array}{l}\text { People holding facilities } \\
\text { waste disposal }\end{array}$ \\
\hline $\begin{array}{c}\mathrm{N}^{\circ} \text { of } \\
\text { substitute }\end{array}$ & 3 landfills & & 46 landfills \\
\hline $\begin{array}{l}\text { Use of tax } \\
\text { revenues }\end{array}$ & No finalist & $\begin{array}{c}\text { Finalist: resources are intended } \\
\text { to promote reduction activities } \\
\text { and recovery of materials and } \\
\text { energy }\end{array}$ & $\begin{array}{l}\text { Finalist: resources are } \\
\text { allocated to actions of } \\
\text { prevention and recovery } \\
\text { operations and optimization } \\
\text { of management of } \\
\text { construction waste as well } \\
\text { as the promotion and } \\
\text { research of applications of } \\
\text { recovered materials. There } \\
\text { are grants financed from } \\
\text { the canon }\end{array}$ \\
\hline Collection & $237,120 €$ & NAD & $6,120,231.62$ \\
\hline $\begin{array}{l}\text { Accrual } \\
\text { period }\end{array}$ & Quarterly & Annual & Quarterly \\
\hline
\end{tabular}

Source: Adaptation from Puig Ventosa and González Martínez (2012)

To analyze the incidence of this type of taxes, we consider as a reference the region of Madrid from the information provided by Ministry of environment and territory of 
Madrid (2006) $)^{2}$. The provision of C\&D waste was significantly reduced from 2003 (year of introduction of the tax) to 2009. Thus, while in 2002 just over 8 million tons of C\&D waste poured on deposit controlled, in 2009 this number decreased to almost 779,000 tons. With the limited information available and the fact that the introduction of the tax was accompanied by a package of measures ${ }^{3}$, it is difficult to identify their contribution to the observed drastic decrease in landfilling of RCD in Madrid, although it seems clearly contributed to this progress (Puig Ventosa and González Martínez, 2012).

\subsection{Other general measures}

This third group of measures includes a number of initiatives, both private and public, that have emerged aimed to the creation of a market for recycling of C\&D waste. Specifically, it seeks to mobilize markets, addressing R\&D activity in order to improve the product and get an image enhanced.

These general measures, referred to in the Symonds Report, (1999) highlights the most widely used both by the different Member States and at EU level: aid for R\&D with various projects or management plans aimed at waste recycling and demonstration projects.

\section{Conclusions}

The EMS based on C\&D waste present a great heterogeneity among different EU countries due mainly to the different levels of environmental protection. Specifically, while the northern countries have high levels of recycling, southern countries are characterized by a market for recycled aggregates almost nonexistent. In the case of Spain, the management of C\&D waste is marginal, given the abundance of natural aggregates at a competitive price, eliminating incentives to recycling process of these wastes.

\footnotetext{
${ }^{2}$ We only have available information for this region.

${ }^{3}$ These measures are the following: the creation of a regional network of public facilities for C\&D waste management, the proposal of the establishment of a proportional bail in relation with the volume of C\&D waste generated, sealing and restoration of municipal landfill debris whose facilities were not adapted to the current legislation (Royal Decree 1481/2001), which regulates waste disposal by landfill and updating the inventory of inert waste landfills in the region of Madrid.
} 
This European North-South duality reveals a positive correlation between these two aspects and the need for government to develop effective measures for better management of $C \& D$ Waste. For this reason, in this paper we set the main measures in environmental policy in the construction and demolition industry that could have a positive impact on increasing recycling of $C \& D$ waste in Spain. From a regional perspective, although progress has been marginal in most Spanish areas, there are three regions that have achieved significant growth, primarily through the fiscal impulse: Madrid, Murcia and Catalonia.

Despite the prominence of regulatory aspects, factors influencing the recovery of C\&D waste are of four types: regulatory / legislative, technical, market and economic. On this basis, public measures provided for optimal management of $C \& D$ waste are grouped into three groups: regulation, environmental taxation and other general measures. However, the most effective measure is a combination of them aimed at restricting the dumping of waste along with the increase in the price of container in these dumps. Finally, we highlight the very important role of public awareness in all the above aspects since it is the final step towards sustainable development in today's society.

\section{References}

Aneiros Rodríguez, L.M. (2008). Gestión de RCD y su repercusión en el desarrollo sostenible. Residuos, 102, 48-60.

Bovenberg, L. y De Mooij, R. (1994). Environmental Levies and Distortionary Taxation. The American Economic Review, 94(4), 1085-1089.

Brito De Aquino, M.; De Jesus Balieiro, T.; Almeida Gomes, A.; Araújo De Faria, M. (2013). The reverse logistics as an environmental tool integrated to environmental management system for an effective management of solid industrial waste. Progress in Industrial Ecology, 8(3), 205 - 220

Burgos, J. (2005). El impuesto sobre la renta de las personas físicas. Hacia una figura tributaria más justa y eficiente. Información Comercial Española. Revista de Economía, $\mathrm{n}^{\circ}$ 826, Madrid.

Calvo, N.; Varela-Candamio, L. and Novo-Corti, I. (2014). A Dynamic Model for Construction and Demolition (C\&D) Waste Management in Spain: Driving Policies Based on Economic Incentives and Tax Penalties. Sustainability, 6(1), 416-435 
C\&D WASTESR (2011). Construction and Demolition Waste Status Report). Management of construction and demolition waste in Australia. Hyder Consulting. Encycle Consulting and Sustainable Resource Solutions. Hyder Consulting Pty LtdABN $76104 \quad 485$ 289, 2011, Melbourne, Australia. Available online:http://www.environment.gov.au/system/files/resources/323e8f22-1a8a-4245a09c-006644d3bd51/files/construction-waste.pdf (accessed on 1106 2013)

Cooper, J.C. (1996). Controls and incentives: a framework for the utilization of bulk wastes. Waste Management, 16 (1-3), 209-213.

Dijkgraaf E. and Vollebergh, H.R.J. (2004). Burn or bury? A social cost comparison of final waste disposal methods. Ecological Economics, 50(3-4), 233-247

Dosal, E.; Coronado, M.;Muñoz, I.; Viguri, J.R. and Andrés, A. (2012). Application of multi-criteria decisión-making tool to locate construction and demolition waste (C\&DW) recycling facilities in a northern Spanish region. Environmental Engineering and Management Journal, 11(3), 545-556.

European Commision (2004). Management of construction and demolition waste. Working document no.1 Belgium: Brussels; 2000 (April, 25, 2004): Available online: http://www.europa.eu.int (accessed on 2305 2013)

European Commision (2011). Service contract on management of construction and demolition waste - sr. A project under the Framework contract ENV.G.4/FRA/2008/0112 (Final report Task 2). Available on: http://ec.europa.eu/environment/waste/pdf/2011_CDW_Report.pdf

Galindez, M. (2003). La gestión empresarial de los Residuos de Construcción y Demolición. I Congreso Nacional de Demolición y Reciclaje. GERD.

Goulder, L. (1994). Environmental Taxation and the Double Dividend: a Reader's Guide, Working Paper $n^{\circ}$ 4896, National Bureau of Economic Research, Cambridge, USA.

Kemp, R.; Pontoglio, S. (2011). The innovation effects of environmental policy instruments-A typical case of the bling men and the elephant? Ecological Economics, 72, 28-36.

Kibert, C. J. (2008). Sustainable construction. Green building design and delivery, John Wiley \& Sons: New Jersey.

Leal Filho, W.; Manolas, E.; Luiz Gonçalves Quelhas, O.; Luiz Braga França, S. (2013). Applying an ethical decision-making model: the case of Avco Environmental. Progress in Industrial Ecology, 8(3), 135 - 144 
Lu, W. and Yuan, H. (2011). A framework for understanding waste management studies in construction. Waste Management, 31, 1252-1260.

Lu, W. and Yuan, H. Exploring critical success factors for waste management in construction projects of China. (2010). Resources, Conservation and Recycling, 55, 201-208.

Lu, W.; Yuan, H.; Li, J.; Hao, J.J.L.; Hi, X. and Ding, Z. (2011). An empirical investigation of construction and demolition waste generation rates in Shenzhen city, South China. Waste Management, 31, 680-687.

Manowong, E., (2012). Investigating factors influencing construction waste management efforts in developed countries: an experience from Thailand. Waste Management and Research, 30(1), 56-71

Ministry of environment and territory of Madrid (2006). Regional Plan of C\&D waste in the Community of Madrid (2006-2016).

PNRCD, 2000-2006. I Plan Nacional de Residuos de la Construcción y Demolición. Ministerio de Medio Ambiente. Secretaría general de Medio Ambiente. Dirección General de Calidad y Evaluación Medioambiental. 2001. Available online: http://www.boe.es/boe/dias/2001/07/12/pdfs/A25305-25313.pdf (accessed on 1403 2013).

PNRCD, 2007-2015. II Plan Nacional de Residuos de Construcción y Demolición 20072015. Anexo 6 del Borrador del Plan Nacional Integrado de Residuos (PNIR). Ministerio de Medio Ambiente. 2007. Available online: http://www.boe.es/boe/dias/2009/02/26/pdfs/BOE-A-2009-3243.pdf (accessed on 2301 2013)

Puig Ventosa, I. and González Martínez, A.C. (2012). Los impuestos sobre el vertido y la incineración de residuos en España. Crónica tributaria, nº 143,155-184

Report from the European Environment Agency (2002).

Symonds Report to the XI General Direction of the European Commission. (1999). "Practice management of C\&D waste and its economic impact"

Sroufe, R. (2003). Effects of Environmental Management Systems on Environmental Management Practices and Operations. Production and Operations Management, 12(3), 416-431. 
Varela Candamio, L. and García Álvarez, M.T. (2010). La reforma fiscal verde en España: un nuevo impulso fiscal. Boletín económico de ICE, $\mathrm{n}^{0} 3002$, 27-38 